\title{
Overweight at age two years in a multi-ethnic cohort ( $A B C D$ study): the role of prenatal factors, birth outcomes and postnatal factors
}

\author{
Marieke LA de Hoog ${ }^{1,2^{*}}$, Manon van Eijsden², Karien Stronks ${ }^{1}$, Reinoud JBJ Gemke ${ }^{3}$ and Tanja GM Vrijkotte
}

\begin{abstract}
Background: Childhood overweight/obesity is a major public health problem worldwide which disproportionally affects specific ethnic groups. Little is known about whether such differences already exist at an early age and which factors contribute to these ethnic differences. Therefore, the present study assessed possible ethnic differences in overweight at age 2 years, and the potential explanatory role of prenatal factors, birth outcomes and postnatal factors.

Methods: Data were derived from a multi-ethnic cohort in the Netherlands (the ABCD study). Weight and height data of 3,156 singleton infants at age 2 years were used. Five ethnic populations were distinguished: Dutch native $(n=1,718)$, African descent $(n=238)$, Turkish $(n=162)$, Moroccan $(n=245)$ and other non-Dutch $(n=793)$. Overweight status was defined by the International Obesity Task Force guidelines. The explanatory role of prenatal factors, birth outcomes and postnatal factors in ethnic disparities in overweight (including obesity) was assessed by logistic regression analysis.
\end{abstract}

Results: Compared to the native Dutch (7.1\%), prevalence of overweight was higher in the Turkish (19.8\%) and Moroccan (16.7\%) group, whereas the prevalence was not increased in the African descent (9.2\%) and other non-Dutch (8.8\%) group. Although maternal pre-pregnancy body mass index partly explained the ethnic differences, the odds ratio (OR) of being overweight remained higher in the Turkish (OR: 2.66; 95\%Cl: 1.56-4.53) and Moroccan (OR: 2.11 ; 95\%Cl: 1.31-3.38) groups after adjusting for prenatal factors. The remaining differences were largely accounted for by weight gain during the first 6 months of life (postnatal factor). Maternal height, birth weight and gender were independent predictors for overweight at age 2 years, but did not explain the ethnic differences.

Conclusion: Turkish and Moroccan children in the Netherlands have 2- to 3-fold higher odds for being overweight at age 2 years, which is largely attributed to maternal pre-pregnancy BMI and weight gain during the first 6 months of life. Further study on the underlying factors of this early weight gain is required to tackle ethnic differences in overweight among these children.

Keywords: body mass index (BMI), childhood, ethnicity, overweight, weight gain

\section{Background}

Childhood obesity is a major public health issue $[1,2]$. In the Netherlands, trends over time show the prevalence of overweight and obesity in school-aged children increasing at an even a faster rate, and at earlier ages, than two decades ago $[3,4]$. However, an earlier study

\footnotetext{
* Correspondence: m.l.dehoog@amc.uva.nl

'Department of Public Health, Academic Medical Centre, University of

Amsterdam, Amsterdam, the Netherlands

Full list of author information is available at the end of the article
}

on childhood overweight showed a decline in overweight prevalence in Dutch girls (3-16 years) [5], and the obesity epidemic in European pre-school children seems to have stabilized [6].

Childhood overweight/obesity is directly related to a decrease in the quality of life of the child concerned [7], which emphasizes the importance of adequate prevention of overweight in children. Moreover, overweight/obese children are at increased risk of developing obesity at adult age which, in turn, is associated with various comorbidities, 
such as type II diabetes, cardiovascular disease, osteoporosis and depression [8-10].

Childhood overweight disproportionally affects some ethnic minority populations $[11,12]$, which is consistently reported in American and European studies [5,13-16]. For example, Fredriks et al. found that overweight and obesity were much more prevalent in Turkish and Moroccan children compared to Dutch children, from age 2 years onwards [13].

Several factors can play a role in the development of overweight and, consequently, in ethnic disparities in overweight $[17,18]$. The developmental origins of disease hypothesis states that as early as the intrauterine period, environmental effects on human health and disease may occur as a result of prenatal, or even pre-conceptional characteristics of the mother, for example maternal body mass index (BMI), smoking, diabetes or hypertensive status [10,19-21]. Previous results from the ABCD study showed that pre-pregnancy $\mathrm{BMI}$ is an independent determinant for BMI of the child at the age of 14 months [22]. In the context of the child's BMI, however, controversy exists as to the associations and influences of prenatal factors, versus those of birth outcomes and early postnatal factors (e.g. early-life feeding conditions and rapid weight gain) $[10,20,23,24]$. In addition, the extent to which these risk factors for overweight account for ethnic differences in overweight is still unknown. Insight into these contributions is essential to develop effective strategies for early prevention of overweight, taking into account ethnic differences.

The present study explores ethnic disparities in overweight of children at age 2 years, and identifies and quantifies the prenatal factors, birth outcomes and postnatal factors that contribute to the explanation of these differences. We hypothesize that overweight at age 2 years will be more prevalent in children from ethnic minorities and that early life factors associated with overweight at early age may explain these differences.

\section{Methods}

\section{Subjects}

The Amsterdam Born Child and their Development (ABCD) study is a multi-ethnic birth cohort study conducted in Amsterdam, the Netherlands. The design and rationale of the $A B C D$ study have been described previously [25]. In brief, between January 2003 and March 20048,266 pregnant women were included in the study after their first antenatal visit to an obstetric caregiver (phase 1). They filled out an extensive pregnancy questionnaire about socio-demographic data, obstetric history, lifestyle, dietary habits, and psychosocial conditions. Of these respondents, 7,863 women gave birth to a viable singleton infant and 6,575 women gave permission to collect information about their child's growth and infant feeding pattern, obtained from the Youth Health Care registration office of the public Health Service in Amsterdam (phase 2 ). Data on weight and height at age 2 years (104 weeks; range 100-160 weeks) were digitized for 3,432 children. The remaining children had moved to another city, or had missing data at age 2 years. Due to missing covariates the final sample for analysis comprised 3,156 children divided into five ethnic groups: Dutch native $(n=1,718)$, African descent (Surinam-Creole, Antilles, Ghana and other South Saharan African countries; $\mathrm{n}=238)$, Turkish $(\mathrm{n}=162)$, Moroccan $(\mathrm{n}=245)$ and other $(\mathrm{n}=793)$. The "other" group comprises children from different western and nonwestern countries. Ethnicity was based on the country of birth of the pregnant woman and her mother, to include both first-generation women (born outside the Netherlands) and second-generation women (born in the Netherlands, but whose mother was born in another country).

Ethical approval of the study was obtained from the Central Committee on Research involving Human Subjects in the Netherlands, the Medical Ethical Committees of participating hospitals, and from the Registration Committee of the Municipality of Amsterdam. All participating women gave written consent.

\section{Measurements}

\section{Main exposure}

Height and weight were measured following a standard procedure by trained nurses, on average 14 times between birth and age 4 years. The primary outcome variable for this study was overweight (yes vs. no) of the child at age 2 years (mean age: 2 years and 3 months), which is a regular follow-up visit conducted at this time. Overweight was defined according to the gender-specific and age-specific International Obesity Task Force (IOTF) BMI guidelines [26]. BMI is a specific and moderately sensitive instrument designed to identify overweight in children from the age of 2 years onwards [26,27].

\section{Potential explanatory factors}

Three groups of potential explanatory factors related to childhood overweight were distinguished based on previous findings [10,18,28,29]: 1) prenatal factors, 2) birth outcomes, and 3) postnatal factors. Prenatal factors included maternal age (years), level of education (years of education after primary school: $\leq 5,6-10,>10$ years), prepregnancy BMI $\left(\mathrm{kg} / \mathrm{m}^{2}\right)$ based on self-reported height and weight, maternal height $(\mathrm{cm})$, hypertension (no, pre-existent, gestational), diabetes (no vs. pre-existent/gestational), parity $(0,1, \geq 2)$, smoking habits (no, $1-5$ or $\geq 6$ cigarettes) and self-reported physical activity (no exercise, low, moderate, vigorous). Physical activity during the previous week was scored by calculating a Metabolic Equivalent (MET) score for the various reported activities using the compendium of physical activities [30]. Birth outcomes were birth weight (kg), gestational age (wk) and gender. Finally, 
postnatal factors were duration of exclusive breastfeeding (none, $<1$ month, 1-3 months or $>3$ months), and the average weight gain per month during the first 6 months of the child's life $(\mathrm{g} / \mathrm{mo})$. This was calculated as the difference between weight at age 6 months and the birth weight divided by the exact age at the 6 -month examination.

\section{Non-response}

The ethnic groups with growth data (response group $\mathrm{n}=$ 3156) were comparable to the ethnic groups (who gave birth to a viable singleton baby) without growth data ( $\mathrm{n}=$ 4707) with respect to almost all measured demographic and lifestyle variables. However, Dutch mothers in the response group were slightly older (32.4 vs. 31.9 years) and higher educated ( $>10$ years after primary school: $59 \%$ vs. $53.9 \%$ ). Multi-parity was more common in the Turkish mothers in the response group (61.3\% vs. 51.5\%), and the mothers in the "other" group were higher educated (> 10 years after primary school: $36.8 \%$ vs. $30.5 \%$ ).

\section{Data analysis}

Differences in baseline characteristics between ethnic groups were examined with $\chi^{2}$-tests (categorical data) or ANOVA (continuous data). After descriptive analysis of the study population, the association between overweight (including obesity), ethnicity, and the role of prenatal factors, birth outcomes and postnatal factors were assessed with multivariable logistic regression. Analyses followed a rational hierarchical format. First, univariable analyses were performed to determine the association of ethnicity and all other potential determinants separately with overweight. Subsequently, 3 models (forced entry) were built to assess the role of the potential explanatory factors in the association between overweight and ethnicity, which included only those covariates with a significance level of $\mathrm{p}<0.10$ in the univariable analysis in order to reduce the number of variables in the model. Correlations between the factors were all below 0.39 , indicating no collinearity. In addition to ethnicity, model 1 included the prenatal factors: maternal age, height, pre-pregnancy BMI, education level, parity, diabetes and physical activity during pregnancy. Model 2 also included birth outcomes (birth weight and gender). The last model (model 3) included the postnatal factor: average infant weight gain during the first 6 months. Finally, we controlled for potential effect modification by use of interaction terms and we found no interactions between ethnicity and all potential explanatory factors in the univariable analyses (Wald test for interaction: $p>0.10$ ), which means that the associations were the same across all ethnic groups.

The results are shown as odd ratios (ORs) and 95\% confidence intervals (CI) using the ethnic Dutch group as reference. Statistical analyses were conducted using SPSS version 16.0 (for windows).

\section{Results}

Table 1 presents the baseline characteristics according to each ethnic group. Dutch women were generally older and had a lower pre-pregnancy BMI compared to the other ethnic groups. The lowest BMI was found in the ethnic Dutch mothers (BMI: 22.6) and the highest in the Turkish (BMI: 24.6) and Moroccan (BMI: 25.1) mothers. Dutch infants showed less weight gain in the first 6 months and a lower BMI at age 2 years compared to the other ethnic groups.

Large differences in the prevalence of overweight in 2year-old children among the ethnic groups were observed, with the highest prevalence among the Turkish (19.8\%) and Moroccan (16.7\%) children, compared with the Dutch children (7.1\%).

Corresponding with the prevalence rates, the OR for overweight was increased in the Turkish (OR: 3.23; 95\%CI: 2.11-4.96) and Moroccan (OR: 2.61; 95\%CI: 1.77-3.84) group compared to the ethnic Dutch group. The odds for overweight in the African descent group (OR: 1.31; 95\%CI: 0.81-2.13) and in the 'other' group (OR: 1.20 ; $95 \%$ CI: 0.881.64) did not differ from the ethnic Dutch group.

\section{Potential explanatory factors}

The univariable analysis (Table 2) showed seven factors that were positively (+) or negatively (-) associated with overweight at age 2 years: maternal age (-), education level $(-)$, maternal height (-), maternal pre-pregnancy BMI (+), physical activity level (-) (prenatal factors), birth weight $(+)$ (birth outcome), and weight gain in the first 6 months of life $(+)$ (postnatal factor). Parity, diabetes and gender were not associated with overweight at age 2 years; nevertheless, these factors reached significance level below $\mathrm{p}<0.10$ and were included in the multivariable analysis (Table 3).

\section{Prenatal}

In the multivariable analyses, a decrease in ORs was found after adding the maternal prenatal factors in model 1 . The highest contribution to the decrease in ORs in this model was due to the inclusion of maternal pre-pregnancy BMI (Table 3). On average, 17\% of the ethnic differences in overweight were attributed to this single factor in the Turkish and Moroccan group. However, the OR for overweight remained higher in the Turkish (OR: 2.68; 95\%CI: 1.58-4.55) and Moroccan (OR: 2.12; 95\%CI: 1.33-3.40) groups compared to the ethnic Dutch group.

\section{Birth outcomes}

Adding the birth outcomes in model 2 hardly attenuated the ORs in most ethnic groups (Table 3). The measured birth outcomes (birth weight and gender) were associated with overweight, but did not explain the ethnic differences. 
Table 1 Characteristics of the study sample according to ethnic group

\begin{tabular}{|c|c|c|c|c|c|}
\hline & Dutch $N=1718$ & African descent $\mathrm{N}=238$ & Turkish $\mathrm{N}=162$ & Moroccan N = 245 & Others $\mathrm{N}=793$ \\
\hline \multicolumn{6}{|l|}{ Prenatal pre-pregnancy factors } \\
\hline Age (year) & $32.4(4.1)^{1}$ & $29.0(6.3)$ & $26.5(5.2)$ & $27.6(5.5)$ & $31.3(5.1)$ \\
\hline \multicolumn{6}{|l|}{ Parity (\%) } \\
\hline 0 & 60.9 & 46.2 & 39.5 & 47.3 & 54.5 \\
\hline 1 & 31.7 & 27.3 & 35.8 & 27.3 & 32.4 \\
\hline$\geq 2$ & 7.5 & 26.5 & 24.7 & 25.3 & 13.1 \\
\hline \multicolumn{6}{|l|}{ Maternal education (\%) } \\
\hline $0-5$ years & 7.0 & 42.6 & 56.5 & 54.2 & 22.4 \\
\hline $6-10$ years & 34.3 & 47.8 & 38.5 & 40.8 & 40.0 \\
\hline$>10$ years & 58.7 & 9.6 & 5.0 & 5.0 & 37.6 \\
\hline Height (cm) & $171(6.2)$ & $166(6.2)$ & $162(5.1)$ & $164(6.7)$ & $166(7.2)$ \\
\hline BMI mother $\left(\mathrm{kg} / \mathrm{m}^{2}\right)$ & $22.6(3.3)$ & $24.4(5.2)$ & $24.6(4.6)$ & $25.1(4.4)$ & $22.7(3.8)$ \\
\hline \multicolumn{6}{|l|}{ Hypertension (\%) } \\
\hline Pre-existent & 3.2 & 3.8 & 3.1 & 4.7 & 3.6 \\
\hline Gestational & 11.8 & 8.9 & 5.0 & 7.2 & 7.4 \\
\hline \multicolumn{6}{|l|}{ Diabetes (\%) } \\
\hline Pre-existent & 0.5 & 2.1 & 1.9 & 2.4 & 0.8 \\
\hline Gestational & 0.1 & 0.8 & 0.6 & 0.0 & 0.4 \\
\hline \multicolumn{6}{|l|}{ Smoking (\%) } \\
\hline None & 90.4 & 89.5 & 80.2 & 97.6 & 90.0 \\
\hline 1-5 cigarettes/day & 6.2 & 7.6 & 13.0 & 1.2 & 6.2 \\
\hline$\geq 6$ cigarettes/day & 3.4 & 3.0 & 6.8 & 1.2 & 3.8 \\
\hline \multicolumn{6}{|l|}{ Physical activity (\%) } \\
\hline Not & 6.6 & 34.5 & 32.7 & 34.7 & 20.1 \\
\hline Low & 19.5 & 41.6 & 50.0 & 39.6 & 28.4 \\
\hline Moderate & 32.0 & 16.4 & 11.7 & 20.8 & 23.8 \\
\hline High & 41.9 & 7.6 & 5.6 & 4.9 & 27.7 \\
\hline \multicolumn{6}{|l|}{ Birth outcomes } \\
\hline Birth weight (kg) & $3.51(0.55)$ & $3.26(0.62)$ & $3.39(0.53)$ & $3.46(0.50)$ & $3.39(0.54)$ \\
\hline Gestational age (wk) & $39.9(1.7)$ & $39.3(2.0)$ & $39.5(1.8)$ & $40.0(1.5)$ & $39.8(1.7)$ \\
\hline \multicolumn{6}{|l|}{ Gender (\%) } \\
\hline Boy & 50.8 & 47.1 & 50.0 & 53.5 & 46.5 \\
\hline Girl & 49.2 & 52.9 & 50.0 & 46.5 & 53.5 \\
\hline \multicolumn{6}{|l|}{ Postnatal factors } \\
\hline \multicolumn{6}{|l|}{ Exclusive breastfeeding (\%) } \\
\hline None & 18.5 & 18.9 & 5.6 & 12.2 & 18.3 \\
\hline$<1$ month & 7.1 & 12.6 & 17.3 & 13.1 & 8.6 \\
\hline 1-3 months & 30.7 & 40.3 & 31.5 & 42.0 & 30.9 \\
\hline$>3$ months & 43.7 & 28.2 & 45.7 & 32.7 & 42.2 \\
\hline $\begin{array}{l}\text { Infant weight gain during the first } 6 \\
\text { months }(100 \mathrm{~g} / \mathrm{mo})\end{array}$ & $7.07(1.34)$ & $7.60(1.56)$ & $7.83(1.50)$ & $7.79(1.47)$ & $7.10(1.35)$ \\
\hline BMI 2 yr $\left(\mathrm{kg} / \mathrm{m}^{2}\right)$ & $16.2(1.3)$ & $16.2(1.4)$ & $16.8(1.7)$ & $16.9(1.7)$ & $16.1(1.4)$ \\
\hline Overweight 2 yr (\%) & 7.1 & 9.2 & 19.8 & 16.7 & 8.8 \\
\hline
\end{tabular}

${ }^{1}$ Mean (SD) (all such values)

\section{Postnatal}

Finally, after adding the postnatal factor 'average infant weight gain during the first 6 months' in model 3, the largest decrease in ORs was seen (Table 3). On average, in the Turkish and Moroccan groups, 33\% of the ethnic differences in overweight were attributed to early weight gain. The ORs for overweight became non-significant in the Turkish and Moroccan groups.
The final model (model 3), revealed that maternal prepregnancy BMI $\left(\mathrm{kg} / \mathrm{m}^{2}\right.$; OR: 1.07 95\% CI: 1.04-1.10), maternal height (cm; OR:0.98; 95\%CI: 0.96-1.00), birth weight (kg; OR:2.55; 95\%CI: 1.95-3.34), gender (girls: OR:2.61; 95\%CI: 1.96-3.48) and early weight gain (per $100 \mathrm{~g} / \mathrm{mo}$;OR:1.82; 95\%CI: 1.65-2.01) were independently associated with overweight of the child at age 2 years. 
Table 2 The odds ratio (OR $95 \% \mathrm{Cl}$ ) of being overweight at age 2 years associated with selected prenatal factors, birth outcomes and postnatal factors

\begin{tabular}{|c|c|c|}
\hline Overweight yes/no & $\mathrm{N}$ & OR $(95 \% \mathrm{Cl})$ \\
\hline \multicolumn{3}{|l|}{ Prenatal factors } \\
\hline Age mother (years) & 3156 & $0.96(0.94,0.99)$ \\
\hline \multicolumn{3}{|l|}{ Parity } \\
\hline 0 & 1768 & 1.00 \\
\hline 1 & 991 & $1.28(0.98,1.67)$ \\
\hline$\geq 2$ & 397 & $1.27(0.93,1.92)$ \\
\hline \multicolumn{3}{|l|}{ Education } \\
\hline $0-5$ & 614 & $1.76(1.29,2.41)$ \\
\hline $6-10$ & 1170 & $1.19(0.89,1.58)$ \\
\hline$>10$ & 1342 & 1.00 \\
\hline Height mother (cm) & 3156 & $0.98(0.96,1.00)$ \\
\hline BMI mother & 3156 & $1.09(1.07,1.12)$ \\
\hline \multicolumn{3}{|l|}{ Hypertension } \\
\hline None & 2717 & 1.00 \\
\hline Pre-existent & 107 & $1.29(0.70,2.38)$ \\
\hline Gestational & 306 & $0.95(0.62,1.44)$ \\
\hline \multicolumn{3}{|l|}{ Diabetes } \\
\hline None & 3120 & 1.00 \\
\hline Pre-existent/gestational & 36 & $2.45(1.06,5.64)$ \\
\hline \multicolumn{3}{|l|}{ Smoking } \\
\hline None & 2847 & 1.00 \\
\hline 1-5 cigarettes & 198 & $0.81(0.56,1.57)$ \\
\hline$\geq 6$ cigarettes & 109 & $1.19(0.59,2.12)$ \\
\hline \multicolumn{3}{|l|}{ Physical activity } \\
\hline None & 492 & 1.00 \\
\hline Low & 837 & $0.92(0.64,1.32)$ \\
\hline Moderate & 848 & $0.82(0.57,1.19)$ \\
\hline High & 978 & $0.63(0.43,0.91)$ \\
\hline \multicolumn{3}{|l|}{ Birth outcomes } \\
\hline Birth weight (kg) & 3156 & $1.69(1.34,2.12)$ \\
\hline Gestational age (weeks) & 3156 & $1.00(0.93,1.07)$ \\
\hline \multicolumn{3}{|l|}{ Gender child } \\
\hline Boy & 1566 & 1.00 \\
\hline Girl & 1590 & $1.27(0.99,1.62)$ \\
\hline \multicolumn{3}{|l|}{ Postnatal factors } \\
\hline \multicolumn{3}{|l|}{ Excl. breastfeeding } \\
\hline None & 547 & $1.19(0.85,1.68)$ \\
\hline$<1$ month & 280 & $1.40(0.93,2.13)$ \\
\hline 1-3 months & 1022 & $1.06(0.80,1.42)$ \\
\hline$\geq 4$ months & 1307 & 1.00 \\
\hline $\begin{array}{l}\text { Infant weight gain during the first } 6 \text { months } \\
(100 \mathrm{~g} / \mathrm{mo})\end{array}$ & 3156 & $1.58(1.45,1.72)$ \\
\hline
\end{tabular}

\section{Discussion}

This study examined ethnic differences in overweight in children of pre-school age, including the role of potential explanatory factors. Results showed that children from Turkish and Moroccan origin have a 2- to 3-fold higher OR for overweight at age 2 years compared to ethnic
Dutch children. Children from African descent and those in the 'other' group did not have higher rates of overweight. Several factors associated with overweight were found, however, they did not necessarily explain the ethnic differences in overweight. Although the mechanisms of differences in childhood overweight in the Turkish and Moroccan infants are not completely understood, the explanatory role of maternal pre-pregnancy BMI, and mainly infant weight gain, were large.

Similar to our results, previous Dutch studies on ethnic differences in overweight found the largest prevalence of overweight (25-30\%) in Turkish and Moroccan children $[11,13]$. Other US and European studies also found large ethnic differences in overweight $[14,15,28,29,31]$. The results of studies comparing overweight rates of African children with the natives are conflicting $[10,15,16,28$, 31,32]. This absence of consensus may be due to different age groups and differences between the African countries included in these latter studies. In the present study, the 'African descent' group was based on comparable backgrounds and the children were relatively young. Most of the above-mentioned studies examined overweight prevalence in older children [5,14,29,31]. We showed that such differences in the Turkish and Moroccan children already exist at age 2 years. It is possible that overweight in African descent children becomes more prevalent at older ages.

Many risk factors for child overweight are more prevalent in ethnic minority groups [18]. As in our study, others have reported the importance of maternal prepregnancy BMI for ethnic differences in overweight in young children $[10,22]$. Recent results from the $A B C D$ study, and a comparable study by Salsberry et al., showed that women from ethnic minority groups have the highest prevalence in overweight, with pre-pregnancy BMI as a strong predictor for high BMI of the pre-school aged child [10,22].

Several mechanisms could explain the association between pre-pregnancy BMI and weight/BMI of young children. 1) Genetic factors, which are passed from mother to child, could have a large effect on the variation in childhood BMI [33-35]. However, most studies on this topic have been conducted among Caucasian populations, while in populations with a lower socio-economic status, environmental effects may have a larger impact [36]. 2) Overweight in children may be propagated and enhanced at an early stage because of an abnormal metabolic environment in utero. Studies show that, in obese women, during gestation changes in hormonal mediators occur due to programming, that could result in more adverse adiposity metabolism in the child [20,21,37]. 3) A high BMI in the mother could result in enhanced foetal exposure to insulin and leptin, affecting its programming of energy balance and appetite regulation [21,37]. Finally, 
Table 3 Differences in prevalence of overweight at age 2 years associated with ethnicity using native Dutch children as reference (crude and multivariable adjusted Ors, 95\% Cis)

\begin{tabular}{lllll}
\hline Overweight yes/no & $\begin{array}{l}\text { Crude } \\
\text { OR }(\mathbf{9 5 \%} \text { Cl) }\end{array}$ & $\begin{array}{l}\text { Model 1 } \\
\text { OR }(\mathbf{9 5 \% ~ C l})\end{array}$ & $\begin{array}{l}\text { Model 2 } \\
\text { OR (95\% Cl) }\end{array}$ & $\begin{array}{l}\text { Model 3 } \\
\text { OR (95\% Cl) }\end{array}$ \\
\hline Ethnicity & & & 1.00 & 1.00 \\
Dutch & 1.00 & 1.00 & $1.20(0.69,2.07)$ & $0.79(0.44,1.41)$ \\
African descent & $1.31(0.81,2.13)$ & $1.11(0.65,1.92)$ & $2.64(1.55,4.51)$ & $1.74(0.99,3.04)$ \\
Turkish & $3.23(2.11,4.96)$ & $2.68(1.58,4.55)$ & $2.07(1.29,3.33)$ & $1.41(0.86,2.31)$ \\
Moroccan & $2.61(1.77,3.84)$ & $2.12(1.33,3.40)$ & $1.22(0.87,1.71)$ & $1.14(0.81,1.62)$ \\
Others & $1.20(0.88,1.64)$ & $1.21(0.86,1.70)$ & \\
\hline
\end{tabular}

Abbreviations: $\mathrm{OR}=$ odds ratio; $\mathrm{Cl}=$ confidence interval.

Model 1: including maternal age, height, pre-pregnancy BMI, education level, parity, diabetes and physical activity during pregnancy.

Model 2: as in model 1; with additional inclusion of birth weight and gender.

Model 3: as in model 2; with additional inclusion of infant weight gain during the first 6 months (100 g/mo).

animal studies showed that overfeeding in early life (in utero and early postnatal) has a great impact on nutrient balance and hormone responses which can lead to a disturbance of appetite regulation [38].

This disturbance in appetite regulation can also influence the amount of weight gained in the first period of life, which we found to be the most important determinant explaining ethnic differences in overweight. Alternatively, early weight gain may be strongly related to social and/or environmental factors, particularly eating habits $[23,24,39]$. A long duration of breastfeeding (up to 4-12 months) is reported to be protective against childhood overweight $[40,41]$ but was not confirmed in the present study; however, conflicting results have been reported related to breastfeeding. Other factors during the weaning period or shortly thereafter (e.g. establishing a family's diet and lifestyle) may overrule the effect of breastfeeding [41,42]. Alternatively, the young age of the participants in the present study might explain overweight. The ethnic differences in weight gain in the Turkish and Moroccan children may be due to cultural differences. Compared with ethnic Dutch parents, Turkish parents introduce fruit juices and snacks much earlier (6 vs 9 months) and both Turkish and Moroccan parents use supplemental feeding more frequently $[43,44]$. Furthermore, in Turkish families a 'chubby' infant is often perceived as a more healthy infant, and sometimes represents wealth and good motherhood [45]. The extra feeding and earlier introduction of solid food might promote overweight in early life in these children.

One strength of the present study is the large number of population-based participants, including many nonDutch, followed from early pregnancy onwards. In addition, many known risk factors for overweight were included $[17,46]$.

Nevertheless, some limitations need to be addressed. First, the Dutch mothers included in the present study (response group with growth data) have a higher educational level and were generally older. Due to this selection, the prevalence of overweight may be underestimated. Second, although this study is representative for the population living in the urban part of the Netherlands, some ethnic minority groups were slightly under-represented. Due to small numbers we were unable to analyse all ethnic groups separately. Therefore, interpreting the results (particularly for the 'other' group) was relatively difficult. Third the pre-pregnancy BMI of women was based on self-reported height and weight. Self-reported height tends to be slighted overestimated and weight underestimated, resulting in an underestimation of BMI [47]. Nevertheless, such underestimation will probably be very similar among all ethnic minority groups. Fourth, we had no data on paternal BMI and maternal weight gain during pregnancy. Paternal genetics and environmental effects are known to influence a child's growth [48]. Furthermore, maternal weight gain during pregnancy (specifically in combination with high pre-pregnancy BMI) is associated with birth weight and weight gain in the first period of life [49-51]. Finally, although odds ratios decreased (with an increasing number of explanatory factors in models), the confidence intervals reported in the multivariable analysis remained overlapping in the models. Therefore, these findings should be interpreted with caution.

\section{Conclusion}

The high rate of overweight in the Turkish and Moroccan children, which already exists at age 2 years, emphasizes the need for better understanding of the explanatory factors contributing to this condition. The present study shows that maternal pre-pregnancy BMI and weight gain during the first 6 months of life made a large contribution to the ethnic differences in overweight. Future studies should focus on the underlying factors of early weight gain and the ethnic components, which may reveal new opportunities for the prevention of overweight in young children. 


\section{Acknowledgements}

The ABCD-study was supported by the Academic Medical Centre (AMC), Amsterdam, the Public Health Services (GGD), Amsterdam, and the Netherlands Organization for Health Research and Development (ZonMw), The Hague. This work would not have been possible without the participants, the midwife practices, the hospitals and the youth health care centers in Amsterdam, the Netherlands.

\section{Author details}

'Department of Public Health, Academic Medical Centre, University of Amsterdam, Amsterdam, the Netherlands. ${ }^{2}$ Department of Epidemiology, Documentation and Health Promotion, Public Health Service of Amsterdam (GGD), Amsterdam, the Netherlands. ${ }^{3}$ Department of Paediatrics, VU University Medical Centre, Amsterdam, the Netherlands.

\section{Authors' contributions}

MLAdH and TGMV developed the concept of the present study as part of the ABCD-study. MLAdH conducted the analyses. All co-authors provided statistical advice. MvE, RBJG and TGMV are the project managers of the $A B C D$ study, and they co-ordinated the data collection. MLAdH was involved in obtaining part of the data. All the authors contributed to interpreting the results and writing the article, and they have seen and approved the final version

\section{Competing interests}

The authors declare that they have no competing interests.

Received: 20 December 2010 Accepted: 1 August 2011

Published: 1 August 2011

\section{References}

1. Speiser PW, Rudolf MC, Anhalt H, Camacho-Hubner C, Chiarelli F, Eliakim A, et al: Childhood obesity. J Clin Endocrinol Metab 2005, 90:1871-1887.

2. Woo JG, Dolan LM, Morrow AL, Geraghty SR, Goodman E: Breastfeeding helps explain racial and socioeconomic status disparities in adolescent adiposity. Pediatrics 2008, 121:458-465.

3. Hirasing RA, Fredriks AM, van Buuren S, Verloove-Vanhorick SP, Wit JM: Toegenomen prevalentie van overgewicht en obesitas bij Nederlandse kinderen en signalering daarvan aan de hand van internationale normen en nieuwe referentiediagrammen. Nederlands Tijdschrift Geneeskunde 2001, 145:1303-1308.

4. Hurk van den $\mathrm{K}$, Dommelen van P, Buuren van $\mathrm{S}$, Verkerk PH, Hirasing RA: Prevalence of overweight and obesity in the Netherlands in 2003 compared to 1980 and 1997. Arch Dis Child 2007, 92:992-995.

5. de Wilde JA, van DP, Middelkoop BJ, Verkerk PH: Trends in overweight and obesity prevalence in Dutch, Turkish, Moroccan and Surinamese South Asian children in the Netherlands. Arch Dis Child 2009, 94:795-800.

6. Cattaneo A, Monasta L, Stamatakis E, Lioret S, Castetbon K, Frenken F, et al: Overweight and obesity in infants and pre-school children in the European Union: a review of existing data. Obes Rev 2010, 11:389-398.

7. Boneberger A, von KR, Milde-Busch A, Bolte G, Rochat MK, Ruckinger S: Association between peer relationship problems and childhood overweight/obesity. Acta Paediatr 2009, 98:1950-1955.

8. Lloyd L, Langley-Evans SC, McMullen S: Childhood obesity and adult cardiovascular disease risk: a systematic review. Int J Obes (Lond) 2009, 34:18-28.

9. Reinehr T, Andler W, Denzer C, Siegried W, Mayer H, Wabitsch M: Cardiovascular risk factors in overweight German children and adolescents: relation to gender, age and degree of overweight. Nutr Metab Cardiovasc Dis 2005, 15:181-187.

10. Salsberry PJ, Reagan PB: Dynamics of early childhood overweight. Pediatrics 2005, 116:1329-1338.

11. Schokker DF, Visscher TL, Nooyens AC, van Baak MA, Seidell JC: Prevalence of overweight and obesity in the Netherlands. Obes Rev 2007, 8:101-108.

12. Leest van LATM, Dis van SJ, Verschuren WMM: Hart- en vaatziekten bij allochtonen in Nederland. Een cijfermatige verkenning naar leefstijl- en risicofactoren, ziekte en sterfte. Bilthoven, RIVM. 2618558006; 2002.

13. Fredriks AM, Buuren van S, Sing RA, Wit JM, Verloove-Vanhorick SP: Alarming prevalences of overweight and obesity for children of Turkish, Moroccan and Dutch origin in The Netherlands according to international standards. Acta paediatr 2005, 94:496-498.
14. Kolsgaard ML, Andersen LF, Tonstad S, Wagensteen T, Joner G: Ethnic differences in metabolic syndrome among overweight and obese children and adolescents: the Oslo Adiposity Intervention Study. Acta paediatr 2008, 97:1557-1563.

15. Saxena S, Ambler G, Cole TJ, Majeed A: Ethnic group differences in overweight and obese children and young people in England: cross sectional survey. Arch dis child 2004, 89:30-36.

16. Whitaker RC, Orzol SM: Obesity among US urban preschool children: relationships to race, ethnicity, and socioeconomic status. Arch Pediatr Adolesc Med 2006, 160:578-684.

17. Reilly JJ, Armstrong J, Dorosty AR, Emmett PM, Ness A, Rogers I, Steer C, Sherriff A: Early life risk factors for obesity in childhood: cohort study. BMJ 2005, 330:1357.

18. Taveras EM, Gillman MW, Kleinman K, Rich-Edwards JW, Rifas-Shiman SL: Racial/Ethnic Differences in Early-Life Risk Factors for Childhood Obesity. Pediatrics 2010, 125:686-695.

19. Barker DJ, Winter PD, Osmond C, Margetts B, Simmonds SJ: Weight in infancy and death from ischaemic heart disease. Lancet 1989, 2:577-580

20. Gluckman PD, Hanson MA, Cooper C, Thornburg KL: Effect of in utero and early-life conditions on adult health and disease. N Engl J Med 2008, 359:61-73.

21. Barker DJ: The developmental origins of adult disease. J Am Coll Nutr 2004, 23:588S-595S.

22. Mesman I, Roseboom TJ, Bonsel GJ, Gemke RJ, van der Wal MF, Vrijkotte TG: Maternal pre-pregnancy body mass index explains infant's weight and BMI at 14 months: results from a multi-ethnic birth cohort study. Arch Dis Child 2009, 94:587-595.

23. Ong KK, Emmett PM, Noble S, Ness A, Dunger DB: Dietary energy intake at the age of 4 months predicts postnatal weight gain and childhood body mass index. Pediatrics 2006, 117:503-508.

24. Stunkard AJ, Berkowitz RI, Schoeller D, Maislin G, Stalling VA: Predictors of body size in the first 2 y of life: a high-risk study of human obesity. Int J Obes Relat Metab Disord 2004, 4:503-513.

25. Eijsden van M, Vrijkotte TG, Gemke RJ, van der Wal MF: Cohort Profile: The Amsterdam Born Children and their Development (ABCD) Study. Int J Epidemiol 2010.

26. Cole TJ, Bellizzi MC, Flegal KM, Dietz WH: Establishing a standard definition for child overweight and obesity worldwide: international survey. BMJ 2000, 320:1240-1243.

27. Reilly JJ, Dorosty AR, Emmett PM: Identification of the obese child: adequacy of the body mass index for clinical practice and epidemiology. Int J Obes Relat Metab Disord 2000, 12:1623-1627.

28. Dennison BA, Edmunds LS, Stratton HH, Pruzek RM: Rapid infant weight gain predicts childhood overweight. Obesity (Silver Spring) 2006, 14:491-499.

29. Kuepper-Nybelen J, Lammerz A, Bruning N, Helebrand J, HerpertzDahlmann B, Brenner H: Major differences in prevalence of overweight according to nationality in preschool children living in Germany: determinants and public health implications. Arch Dis Child 2005, 4:359-363.

30. Ainsworth BE, Haskell WL, Whitt MC, Irwin ML, Swartz AM, Strath SJ, et al: Compendium of Physical Activities: an update of activity codes and MET intensities. Medicine and Science in Sports and Exercise 2000, 32:S498-S516.

31. Ogden CL, Troiano RP, Briefel RR, Kuczmarski RJ, Flegal KM, Johnson CL: Prevalence of overweight among preschool children in the United States, 1971 through 1994. Pediatrics 1997, 99:E1.

32. Anderson SE, Whitaker RC: Prevalence of obesity among US preschool children in different racial and ethnic groups. Arch Pediatr Adolesc Med 2009, 163:344-348.

33. Silventoinen K, Bartels M, Posthuma D, Estourgie-van Burk GF, Willemsen G, van Beijsterveldt TC, et al: Genetic regulation of growth in height and weight from 3 to 12 years of age: a longitudinal study of Dutch twin children. Twin Res Hum Genet 2007, 10:354-363.

34. Silventoinen $\mathrm{K}$, Pietilainen $\mathrm{KH}$, Tynelius $\mathrm{P}$, Sorensen $\mathrm{Tl}$, Kaprio J, Rasmussen F: Genetic regulation of growth from birth to 18 years of age: the Swedish young male twins study. Am J Hum Biol 2008, 20:292-298.

35. Silventoinen K, Rokholm B, Kaprio J, Sorensen TI: The genetic and environmental influences on childhood obesity: a systematic review of twin and adoption studies. Int J Obes (Lond) 2010, 34:29-40.

36. Silventoinen K: Determinants of variation in adult body height. $J$ Biosoc Sci 2003, 35:263-285. 
37. Catalano PM: Obesity and pregnancy-the propagation of a viscous cycle? J Clin Endocrinol Metab 2003, 88:3505-3506.

38. Armitage JA, Poston L, Taylor PD: Developmental origins of obesity and the metabolic syndrome: the role of maternal obesity. Front Horm Res $2008,36: 73-84$

39. bu-Rmeileh NM, Hart CL, McConnachie A, Upton MN, Lean ME, Watt GC: Contribution of Midparental BMI and other determinants of obesity in adult offspring. Obesity (Silver Spring) 2008, 16:1388-1393.

40. Grummer-Strawn LM, Mei Z: Does breastfeeding protect against pediatric overweight? Analysis of longitudinal data from the Centers for Disease Control and Prevention Pediatric Nutrition Surveillance System. Pediatrics 2004, 113:81-86

41. Scholtens S, Gehring U, Brunekreef B, Smit HA, Jongste de JC, Kerkhof M, Gerritsen J, Wijga AH: Breastfeeding, weight gain in infancy, and overweight at seven years of age: the prevention and incidence of asthma and mite allergy birth cohort study. Am J Epidemiol 2007, 165:919-926

42. Hediger ML, Overpeck MD, Kuczmarski RJ, Ruan WJ: Association between infant breastfeeding and overweight in young children. JAMA 2001 285:2453-2460.

43. Bulk-Bunschoten AM, Pasker-de Jong PC, van Wouwe JP, de Groot CJ: Ethnic variation in infant-feeding practices in the Netherlands and weight gain at 4 months. J Hum Lact 2008, 24:42-49.

44. Hulsmann AR, Senyurek A, Oostenbrink R: Verschillen in voedingsgewoonten in het eerste levensjaar tussen Turkse en Nederlandse zuigelingen. Tijdschrif Kindergeneeskunde 2005, 73:201-205.

45. Bulk-Bunschoten AM, van BS, Reerink JD, de Jong PC, de Groot CJ: Weight and weight gain at 4 months (The Netherlands 1998): influences of nutritional practices, socio-economic and ethnic factors. Paediatr Perinat Epidemiol 2002, 16:361-369.

46. Monasta L, Batty GD, Cattaneo A, Lutje V, Ronfani L, van Lenthe FJ, et al: Early-life determinants of overweight and obesity: a review of systematic reviews. Obes Rev 2010, 11:695-708.

47. Stewart AW, Jackson RT, Ford MA, Beaglehole R: Underestimation of relative weight by use of self-reported height and weight. Am J Epidemiol 1987, 125:122-126.

48. Griffiths $L$, Dezateux C, Cole TJ: Differential parental weight and height contributions to offspring birthweight and weight gain in infancy. Int $J$ Epidemiol 2007, 36:104-107.

49. Olson CM, Strawderman MS, Dennison BA: Maternal Weight Gain During Pregnancy and Child Weight at Age 3 Years. Matern Child Health J 2009, 13:839-846.

50. Wrotniak BH, Shults J, Butts S, Stettler N: Gestational weight gain and risk of overweight in the offspring at age $7 \mathrm{y}$ in a multicenter, multiethnic cohort study. Am J Clin Nutr 2008, 87:1818-1824.

51. Frederick IO, Williams MA, Sales AE, Martin DP, Killien M: Pre-pregnancy body mass index, gestational weight gain, and other maternal characteristics in relation to infant birth weight. Matern Child Health 」 2008, 12:557-567.

\section{Pre-publication history}

The pre-publication history for this paper can be accessed here: http://www.biomedcentral.com/1471-2458/11/611/prepub

\section{doi:10.1186/1471-2458-11-611}

Cite this article as: de Hoog et al:: Overweight at age two years in a multi-ethnic cohort ( $A B C D$ study): the role of prenatal factors, birth outcomes and postnatal factors. BMC Public Health 2011 11:611.

\section{Submit your next manuscript to BioMed Central and take full advantage of:}

- Convenient online submission

- Thorough peer review

- No space constraints or color figure charges

- Immediate publication on acceptance

- Inclusion in PubMed, CAS, Scopus and Google Scholar

- Research which is freely available for redistribution

Submit your manuscript at www.biomedcentral.com/submit
Biomed Central 